\title{
CONTENT AND PEDAGOGICAL COMPETENCE OF MATHEMATICS TEACHERS IN THE SECONDARY SCHOOLS IN LA UNION, PHILIPPINES
}

\author{
Feljone G. Ragma

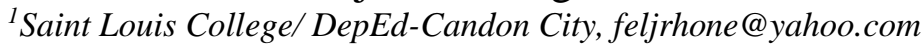

\begin{abstract}
The descriptive research looked into the competence of mathematics teachers in the secondary schools in San Fernando City, La Union, Philippines. It looked into the profile of the teachers; their competence along content and pedagogy; the significant relationship between and among teacher's profile, content and pedagogical competence. It used validated questionnaires and covered 13 schools with heads, faculty, and students as respondents. It found out that the teachers are licensed, pursuing graduate studies, new in teaching and had inadequate seminars. Their level of content competence was average. They scored highest in conceptual and computational but lowest in problem-solving. Conversely, their level of pedagogical competence was very good. They were rated highest in management but lowest in teaching. Moreover, highest educational attainment and number of years of teaching correlate to content competence. Highest educational attainment and number of seminars correlate to pedagogical competence. Also, content correlates to pedagogical competence. The teachers' conceptual and computational skills were strengths. Equally, reasoning and problem-solving were weaknesses. All the other skills under pedagogical competence were strengths except on the quality of utilization of information and communication technology. The researcher concluded that the mathematics teachers were all qualified with very good subject and instructional skills.
\end{abstract}

Keywords: Pedagogy, Content Competence, Mathematics Teaching/Education, Teacher Quality

\section{Introduction}

\section{Background of the Study}

The tremendous task of education today, under the enormous influx of technological advances and innovations, is still the development of a learner into a whole person, a complete human being capable of understanding his own complexity and his intricate society. The teacher, who is in charge of this global task, needs to cope with the challenges of the modern times. He has to be equipped with the resources vital in arousing and sustaining students' interest, in facilitating the learning process, and in evaluating the learning outcomes. He should be a master of his craft and should be genuinely concerned with the total growth and development of his students (Clemente-Reyes, 2002).

Quality education is first and foremost a function of instruction. Thus, for education to attain and sustain its quality, it should be coupled with the best preparation for excellent instruction. It is then emphasized that to be an excellent high school teacher, one should both have full command of the subject and full knowledge of the teaching-learning process. The teacher, therefore, should not only have mastery of the subject matter but also an in-depth understanding of the mind set and standards of students within the class (http://www.dooyoo.co.uk/discussion/what-qualities-make-an-excellent-teacher/1039890/).

The Philippines' vision for quality education with focus on Mathematics Proficiency is undoubted. But, the Philippines is not exempt from troublesome scenarios of lowering performance. In fact, Dr. Milagros Ibe of the University of the Philippines said that the result of a survey on the competence of Science and Mathematics teachers showed that majority of the teachers are not qualified to teach the subjects. In April 2010, the passing rate for secondary teachers was only $23.32 \%$ and in September, 2010 the passing rate was $25.86 \%$. These rates reveal that teachers, though possess the needed degree/s are not yet qualified to teach; thus, they are not competent.

With this reality, it is not surprising why students performed poorly in Mathematics Achievement Test. This is stressed by Roldan (2004) in her assertion that students' mathematics low performance is reflective of the weak mathematics teachers' influence. She revealed that secondary teachers in Region I were proficient only in concepts and computations but they were deficient in their skills in problem-solving and the use of teaching strategies. Thus, mathematics teachers frequently find themselves focusing on mechanics, the answer-resulting

Corresponding Author: Author: Feljone G. Ragma / feljrhone@yahoo.com 
procedures without really teaching what mathematics is all about-where it came from, how it was labored on, how ideals were perceived, refined, and developed into useful theories - in brief, its social and human relevance (Cayabyab,2010).

It is with these situationers that the researcher embarked on the idea to appraise and evaluate the competence of mathematics teachers in the City of San Fernando, La Union, Philippines along content and pedagogy.

\section{Research Questions}

This study determined the level of competence of mathematics teachers in the Private Secondary Schools in San Fernando, La Union, Philippines. Specifically, it aims to answer the following questions:

1. What is the profile of the mathematics teachers along:

a. highest educational qualification;

b. number of years in teaching mathematics; and

c. number of mathematics trainings and seminars attended?

2. What is the level of competence of mathematics teachers along:

a. Content; and

b. Pedagogy?

2.1 What are the major strengths and weaknesses of the mathematics teachers?

3. Is there a significant relationship between and among:

a. Teacher's profile and competence along content and pedagogy?

\section{Research Methodology}

\section{Research Design}

The descriptive survey of investigation was used in the study. This design aims at gathering data about the existing conditions. Calmorin (2005) describes descriptive design as a method that involves the collection of data to test hypothesis or to answer questions regarding the present status of a certain study. This is apt for the study since it endeavored to assess and describe the content and pedagogical competence of the teachers.

\section{Sources of Data}

The population of this study is composed of three (3) groups of respondents: (1) heads, (2) High school mathematics teachers in the Private City schools of San Fernando (3) high school mathematics students for the academic year 2010-2011.

The total population of three hundred and fifty-seven (357) constituted the respondents of this study, broken down as follows: three hundred eighteen (318) students, twenty six (26) teachers and thirteen (13) heads. Substitute teachers or on-leave teachers are not considered as respondents of the study.

\section{Findings and Discussion}

\section{Highest Educational Attainment}

Table 1 shows the highest educational attainment of Mathematics Teachers. Out of the 26 teacher-respondents, 11 or $42.31 \%$ are licensed teachers, 14 or $50.00 \%$ are pursuing graduate studies and 2 or $7.69 \%$ are Master's degree holders. This means that the Mathematics teachers are qualified to teach in the Secondary schools since they have met the necessary requirements stipulated in the Magna Carta for Public School Teachers and Republic Act 9293, which both require secondary teachers to be duly registered before engaging themselves in the teaching profession. It is also noticeable that majority of the teachers value continuing education since half of the total population are currently enrolled in their Master's program. This finding runs parallel to the studies of Fianza (2009), Eslava (2001) and Rulloda (2000) stressing that generally, the teachers meet the basic requirements for teaching and do not want to be stagnant because they want to elevate their professional outlook to make them effective and worthy members of the profession.

\section{Number of Years in Teaching Mathematics}


As seen in Table 1, 18 or $65.38 \%$ have been teaching from $0-5$ years, 2 or $7.69 \%$ from $6-10$ years, 1 or $3.85 \%$ from $11-15$ years, 4 or $15.39 \%$ from $16-20$ years, 1 or $3.85 \%$ from $21-25$ years, and 1 or $3.85 \%$ has been teaching for more than 25 years. These data indicate that the teachers are very young in the profession. It means that the general turn-over of teachers in the private schools is high, especially in small schools where teachers stay only up to 1-2 years since they desire to be employed in the public schools or work abroad, where higher compensation, more incentives and other benefits abound. This finding runs parallel to Fianza (2009) revealing that the teachers are generally quite young in the service.

Table $1 \quad$ Profile of the Mathematics Teachers

\begin{tabular}{lcc} 
Profile Variables & Frequency & Rate \\
\hline A. Highest Educational Attainment & & \\
\hline BSEd/AB/BS Graduate & 11 & $42.31 \%$ \\
\hline BSEd/AB/BS Graduate w/ MS/MA units & 13 & $50.00 \%$ \\
\hline MS/MA graduate & 2 & $7.69 \%$ \\
\hline Total & 26 & $100 \%$ \\
\hline $\begin{array}{l}\text { B. No. of Years in Teaching Mathematics } \\
\text {-5 years }\end{array}$ & 17 & $65.38 \%$ \\
\hline $6-10$ years & 2 & $7.47 \%$ \\
\hline $11-15$ years & 1 & $3.85 \%$ \\
\hline $16-20$ years & 4 & $15.39 \%$ \\
\hline 21-25 years & 1 & $3.85 \%$ \\
\hline 26 years and above & 1 & $3.85 \%$ \\
\hline Total & 26 & $100 \%$ \\
\hline C. No. of Seminars Attended & & $84.62 \%$ \\
\hline $0-10)$ Very Inadequate & 22 & $15.39 \%$ \\
\hline (11-20) Slightly Inadequate & 4 & $100 \%$ \\
\hline Total & 26 & \\
\hline
\end{tabular}

\section{Number of Seminar/Trainings Attended (for the last two years)}

Table 1 also presents that out of the 26 respondents, 22 or $84.62 \%$ have "very inadequate" attendance or participation in trainings and seminars while the remaining 4 or $15.39 \%$ have "slightly adequate" attendance to seminars and trainings. This implies that the teachers have not been sent to seminars and trainings where their participation was highly expected. This is caused by financial constraints, non-availability of teachers due to school commitments and the distance of the venue of the seminar.

The finding of the current study is supported by the finding of Oredina (2006), which disclosed that majority of the teacher-respondents have "very inadequate" participation in seminars and training workshops. This was due to financial constraints. However, it does not jibe with the finding of Fianza (2009), which revealed that more than $50 \%$ of her respondents have attended trainings on curriculum, teaching strategies, management and assessment methods.

\section{Content Competence of the Mathematics Teachers}

Table 2 reveals that the teachers have above average competence in Elementary Algebra, average competence in Intermediate Algebra, above average competence in Geometry; and average competence in Advanced Algebra, Trigonometry and Statistics. Generally, the teachers have "average subject matter competence" in Mathematics. This means that the teachers know what to teach since they have "good" proficiency in the Mathematics subjects offered in the Secondary schools. Since they have average competence in Mathematics, it can be inferred that they are qualified to teach secondary mathematics.

\section{Table 2 Content Competence of the Mathematics Teachers}




\begin{tabular}{|c|c|c|c|c|c|c|c|}
\hline $\begin{array}{l}\text { Area of } \\
\text { Mathematics }\end{array}$ & $\begin{array}{l}\text { Conceptual } \\
\text { Skills }\end{array}$ & $\begin{array}{l}\text { Analytical } \\
\text { Skills }\end{array}$ & $\begin{array}{l}\text { Computational } \\
\text { Skills }\end{array}$ & $\begin{array}{l}\text { Problem- } \\
\text { Solving } \\
\text { Skills }\end{array}$ & Mean & Rating & Remark \\
\hline $\begin{array}{l}\text { Elementary } \\
\text { Algebra }\end{array}$ & 24 & 12 & 19 & 11 & 17 & $\begin{array}{c}\text { Above } \\
\text { Average }\end{array}$ & $\mathrm{S}$ \\
\hline $\begin{array}{l}\text { Intermediate } \\
\text { Algebra }\end{array}$ & 18 & 16 & 19 & 10 & 16 & Average & $\mathrm{W}$ \\
\hline Geometry & 14 & 19 & 21 & 13 & 17 & Average & $\mathrm{W}$ \\
\hline $\begin{array}{l}\text { Advanced } \\
\text { Algebra, } \\
\text { Trigonometry, } \\
\text { and Statistics }\end{array}$ & 17 & 14 & 11 & 12 & 14 & Average & W \\
\hline Grand Mean & 18 & 15 & 18 & 12 & 16 & & \\
\hline Rating & $\begin{array}{c}\text { Above } \\
\text { Average }\end{array}$ & Average & Above Average & Average & & Average & W \\
\hline Remark & $\mathrm{S}$ & $\mathrm{W}$ & $\mathrm{S}$ & $\mathrm{W}$ & & & \\
\hline
\end{tabular}

Moreover, they have above average competence in conceptual skills but average competence in reasoning/ analytical, computational and problem solving. They are competent in the facts, properties and terms in mathematics but they are not so competent in the application of concepts to word problems.

The finding of this study is supported by the findings of Toledo and Bagaforo, as cited by Diaz (2000), which asserted that the teachers have average competence in their knowledge and ability in mathematics. They emphasized that the teachers needed updating and upgrading of subject matter competence to possess the needed competence situated at a level very adequate for teaching secondary mathematics.

As to strengths and weaknesses, the teachers are strong in conceptual and computational skills but are weak in analytical and problem-solving. This indicates that the teachers are really good with facts and computations but are hard up in segmenting a problem into its interrelated parts and applying computations in solving word problems.

\section{Pedagogical Competence}

Table 3 reflects the summary of pedagogical competence of mathematics teachers. It is gleaned from the table that the competence of the teachers obtained a grand mean of 4.24, interpreted as very good.

All the levels of skills were rated very good with management skills as the highest and teaching skills as the lowest. Along teaching skills, one indicator was rated good only, that is on the quality of communication and information technology used. This implies that the teachers are not very familiar and unskillful in utilizing instructional technology; thus, they are not very competent along this area. This is also rooted to the access to such technologies. In the researcher's observation during the proctoring of tests, teachers, especially the ones in the big schools, own laptops. This gives an idea that the math teachers have limited access to projectors since other math teachers and teachers of other subjects also desire to use information and communication technology in facilitating the teaching-learning process.

Preparation of instructional technology is also a cause of this. Creating interactive slides, researching up-to-date clips including the setting up of the gadgets is also a complex task. Reinhardt, as cited by Oredina (2006), emphasizes that using ICT in teaching develops the proficiency desired among the students since features of computers such as video presentations; animations and the like are better instructional objects than chalkboards and transparencies.

The very good evaluation given by the respondent groups to almost all the skills is pinpointing to a laudable instructional competence of the mathematics teachers in the Private schools in the City Division of San Fernando. This means that the mandate of the Department of Education (DepEd) to provide Quality Education for All (EFA) is present such that the realization of the goals and objectives of Mathematics teaching is achievable, especially in the Secondary schools.

The studies of Acantilado (2002), Subala, as cited by Roldan (2004) and Oredina (2006) support the finding of the study. Their studies emphasized that their teacher-respondents were highly competent. Subala explained that since the teachers were competent, they can be proper sources of assistance and guidance to their students in analyzing different mathematical concepts. 
As to strengths and weaknesses, the teachers are strong in their pedagogy but have been found weak in one area only, that is, on the utilization of educational gadgets and tools. More trainings are desired for this purpose.

Table 3 Pedagogical Competence of Mathematics Teachers

\begin{tabular}{lccc}
\hline Level of Instructional Competence & Mean & Rating & Remark \\
\hline $\begin{array}{l}\text { A. Teaching/ Facilitating Skills } \\
\text { 1. Substantiality of Teaching }\end{array}$ & 4.21 & Very Good & S \\
\hline 2. Quality of Teachers' Explanation & 4.31 & Very Good & $\mathrm{S}$ \\
\hline 3. Receptivity to students' ideas and contributions & 4.13 & Very Good & $\mathrm{S}$ \\
\hline 4. Quality of questioning procedure & 4.24 & Very Good & $\mathrm{S}$ \\
\hline 5. Selection of teaching methods & 4.07 & Very Good & $\mathrm{S}$ \\
\hline 6.Quality of information and communication technology used & 3.49 & Good & W \\
\hline Sub-Mean & 4.07 & Very Good & $\mathrm{S}$ \\
\hline B. Guidance Skills & 4.26 & Very Good & $\mathrm{S}$ \\
1. Quality of interaction with students & & & \\
\hline 2. Quality of students' activity & 4.22 & Very Good & $\mathrm{S}$ \\
\hline Sub-Mean & 4.24 & Very Good & $\mathrm{S}$ \\
\hline C. Management Skills & & & \\
\hline 1.Atmosphere in the Classroom & 4.30 & Very Good & $\mathrm{S}$ \\
\hline 2.Conduct and return of evaluation materials & 4.43 & Very Good & $\mathrm{S}$ \\
\hline Sub-Mean & 4.37 & Very Good & $\mathrm{S}$ \\
\hline D. Evaluation Skills & 4.23 & Very Good & $\mathrm{S}$ \\
1. Quality of appraisal questions & & \\
\hline 2.Quality of assignment/enrichment activities & 4.32 & Very Good & $\mathrm{S}$ \\
\hline 3.Quality of appraising students' performance & 4.4 & Very Good \\
\hline Sub-Mean & 4.32 & Very Good & $\mathrm{S}$ \\
\hline Grand Mean & 4.24 & Very Good \\
\hline
\end{tabular}

Legend: $S$-strength; W - weakness

\section{Relationship Between and Among Profile Variables, Content and Pedagogical Competence}

Table 4 summarizes the relationship existing between profile and content competence, profile and instructional competence, and competence along content and instruction.

It reveals that the t-value of the computed correlation coefficients between the profile variables and content competence are all (except for number of seminars attended) greater than the $t$-critcial value of 1.711; thus highest educational attainment, number of years of teaching are significantly related to content competence. This means that the higher the educational attainment and the number of years of teaching, the higher is the content competence of the teachers. It is true that when teachers get the needed educational exposure and get the needed experience, their mathematical foundations get stronger.

Moreover, it divulges that highest educational attainment and number of seminars attended are significantly correlated to instructional competence. This is evidenced by the t-values of 4.08 and 1.83 , respectively, which are higher than the t-critical of 1.711. However, the number of teaching experience attended does not correlate with instructional competence. This means that the higher are the educational attainment and the number of seminars attended to, the more pedagogically competent a teacher is.

It is also revealed in Table 4 that the content and pedagogical competence of the teachers are significantly correlated. This is indicated by the t-value of 2.01 which is greater that the t-critical 1.711. This means that the higher the content competence, the higher is the pedagogical competence. This is supported by the popular claim that "Teachers cannot give what they do not have". Thus, if teachers know what to teach, they likely know how to teach them.

Table 4 Relationship existing Between and Among Profile, Content and Pedagogical Competence

\begin{tabular}{lcccc}
\hline & $\begin{array}{c}\text { Highest Educational } \\
\text { Attainment }\end{array}$ & $\begin{array}{c}\text { Number of Years } \\
\text { of Teaching }\end{array}$ & $\begin{array}{c}\text { Number of } \\
\text { Seminars Attended }\end{array}$ & $\begin{array}{c}\text { Pedagogical } \\
\text { Competence }\end{array}$ \\
\hline Content & 0.40 low & 0.38 low & 0.31 low & 0.38 low \\
Competence & $\mathrm{t}=3.10^{*}$ & $\mathrm{t}=2.01^{*}$ & $\mathrm{t}=1.60$ & $\mathrm{t}=2.01^{*}$ \\
\hline Pedagogical & $0.64 *$ Marked & 0.28 low & 0.35 low & \\
Competence & $\mathrm{t}=4.08^{*}$ & $\mathrm{t}=1.43$ & $\mathrm{t}=1.83^{*}$ & \\
\hline Legend: $*$ Significant & $\mathrm{df}=\mathrm{n}-2=24 ;$ & $\mathrm{t}$ critical value $=1.711$ & & \\
\hline
\end{tabular}

\section{Conclusions and Recommendations}




\section{Conclusions}

1. The mathematics teachers in the secondary schools of the City Division of San Fernando, La Union are all qualified in the teaching profession.

2. The teachers had only average competence in terms of their content competence but were perceived very skillful in teaching Mathematics.

3. Teachers who have higher educational attainment, number of years in teaching not have higher subject matter competence. Similarly, teachers who have higher educational attainment and number of seminars attended to have higher pedagogical competence. More so, teachers with high content competence, has hig pedagogical competence, and vice versa.

4. Teachers are not so skilled at analysis and problem-solving and they do not use ICT and other innovative instructional technology much in their daily teachings but still have very good teaching performance.

\section{Recommendations}

1. The teachers have to be encouraged to enroll in their graduate studies, especially in line with their fields of specialization so that their competence will be elevated.

2. Incentive Scheme for outstanding performance should be devised by administrators to enhance or sustain teaching performance; and keep outstanding teachers in the service.

3. Teachers should always be sent to seminars and workshops where their participation is necessary. If funding isn't enough, there should be mechanisms such as improving faculty development plan to remedy the predicament. Further, if a teacher is sent for a seminar, he has to echo the essentials of the seminar to his/her area members.

4. Teachers should use ICT in their teaching. On the other hand, the school has to provide the materials in order for the teacher to integrate technology to instruction.

5. A closer monitoring system has to be applied by the heads to ensure that teachers utilize ICT in their teaching. If materials are scarce, scheduling should be done.

6. The proposed two-pronged training program for the Mathematics teachers should be implemented in the private secondary schools in the City Division of San Fernando, La Union.

7. A study to determine the efficiency or efficacy of the two-pronged training program should be undertaken.

8. A parallel study should be undertaken in other subject areas such as English and Science.

\section{Acknowledgements}

The Saint Louis College of the City of San Fernando, La Union Philippines is acknowledge for allowing this research to be presented internationally.

The DepEd- Candon City Division and the Candon National High School for allowing the researcher to present abroad.

\section{References}

Calmorin, L. (2005). Methods of research and thesis writing. Manila: Rex Bookstore, Inc.

Cayabyab, S.P., et al. (2009). College algebra for filipino students. Quezon City: C \& E Publishing, Inc.

Calmorin, L (2001). Methods of research and thesis writing. Manila: Rex Book Store

Clemente-Reyes, F (2010). Unveiling Teacher Expertise. Manila: De la Salle University Press,Inc.

Ibe, M. (1998). "Filipino Studes lack Math and Science Skills." The Philippine Journal of Education: 1-3.

Eslava, P.M. (2001). A Proposed Training Program for Mathematics Teachers in the Secondary Schools of La Union, SY 2002-2005. Master's Thesis. Don Mariano Marcos Memorial State University Graduate College, City of San Fernando, La Union, 2001.

Diaz, PU. (200) Predictors of Mathematical Competencies of the Public and Private Secondary Mathematics Teachers of the Division of La Union.Dissertation. Don Mariano Marcos Memorial State University Graduate College, City of San Fernando, La Union 
Feljone G. Ragma / Content and Pedagogical Competence of Mathematics Teachers in the Secondary Schools in La Union, Philippines

Fianza, E (2009). Competencies and Needs of Geometry Teachers: Input to a Training Program. Dissertation. Don

Mariano Marcos Memorial State University Graduate College, City of San Fernando, La Union

Roldan, J (2004). Achievement and Competence of Mathematics Teachers in the Division of La Union: Basis for $a$

Proposed Training Program. Dissertation. Saint Louis College, San Fernando City, La Union

Subala, GF (2006). Competence of the Graduating Math Majors in the Teacher Training Institutions in Region I.

Dissertation. Saint Louis College, San Fernando City, La Union

http://www.dooyoo.co.uk/discussion/what-qualities-make-an-excellent-teacher/1039890 (Acessed October 27, 2010) 